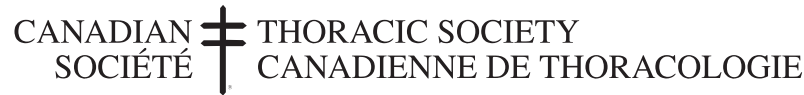

\section{The clinician/scientist in respirology - a vanishing phenotype!}

$\mathrm{T}$ he Canadian Thoracic Society (CTS) has recently identified an urgent need to create a bold new national agenda to expand both fundamental and clinical research in respiratory diseases. An examination of the research environment makes it abundantly clear that it is time for action and, thanks to its Research Committee, the CTS is doing just that - taking decisive action in collaboration with its partners.

Several issues relating to the state of respiratory research in Canada have prompted this course of action.

\section{A diminishing pool of clinician/scientists}

Across Canadian respiratory divisions, only 51 MDs have role descriptions that permit approximately 50\% time protection for research. The majority of these ( 29 of 51) come from the larger centres (eg, The University of Toronto [Toronto, Ontario], The Hospital for Sick Children [Toronto, Ontario] and Laval University [Sainte-Foy, Quebec]). The remaining 22 are thinly distributed among 12 academic divisions. Many well-trained, mid-career clinician/scientists no longer run active research programs.

The increasing burden of respiratory disease in Canada Six million Canadians were diagnosed with respiratory illness in 2007 (1). Respiratory illness is responsible for $11 \%$ of all hospitalizations and $9 \%$ of all deaths in Canada $(1,2)$. Respiratory diseases are the third most frequent cause of 'healthy' years of life lost to morbidity, and rank third among leading causes of death behind cancer and cardiovascular disease. Moreover, respiratory disease is the only major cause of death that continues to increase $(1,2)$. Conservative estimates of the economic burden of respiratory disease are placed at $\$ 9$ billion per year and are likely to rise to as much as $\$ 15.4$ billion per year by 2020 (3).

\section{Reputation as world leader threatened}

It is widely believed that Canadian respiratory researchers 'punch above their weight' on the global stage. In one assessment of research productivity performed by Michalopoulos and Falagas (4), Canadian researchers ranked fourth behind western Europe, the United States and Japan, publishing a total of 2612 articles between 1995 and 2003. This compares with 19,646 articles published by the top-ranked western European respiratory researchers. While Canada has deservedly enjoyed the reputation of being a world leader in the field of respiratory research, there is deepening concern that this rarefied distinction is in danger of becoming eroded.

\section{Le clinicien-chercheur en pneumologie - un phénotype en voie de disparition !}

\begin{abstract}
T a Société canadienne de thoracologie (SCT) a récemment Lconstaté le besoin urgent de créer un nouveau programme audacieux pour accroître tant la recherche fondamentale que clinique sur les maladies respiratoires. L'examen du milieu de la recherche démontre clairement qu'il est temps d'agir et, grâce à son comité de recherche, c'est exactement ce que fait la SCT : prendre des mesures décisives en collaboration avec ses partenaires.

Plusieurs enjeux liés à l'état de la recherche en pneumologie au Canada ont suscité ce plan d'action.
\end{abstract}

Un bassin décroissant de cliniciens-chercheurs

Au sein des unités de pneumologie du Canada, seulement 51 médecins ont une description de tâches qui protège environ $50 \%$ de leur temps pour la recherche. La majorité d'entre eux (29 sur 51) proviennent des grands centres (p. ex., l'université de Toronto [Toronto, Ontario], The Hospital for Sick Children [Toronto, Ontario] et l'Université Laval [Sainte-Foy, Québec]). Les 22 autres sont chichement répartis entre 12 unités universitaires. Bon nombre de cliniciens-chercheurs bien formés en mi-carrière ne dirigent plus de programme de recherche actif.

Le fardeau croissant des maladies respiratoires au Canada On a diagnostiqué une maladie respiratoire chez six millions de Canadiens en 2007 (1). Les maladies respiratoires sont responsables de $11 \%$ de toutes les hospitalisations et de $9 \%$ de l'ensemble des décès au Canada $(1,2)$. Elles constituent la troisième cause en importance des années de vie « en santé » perdues au profit de la morbidité et se situent en troisième place parmi les principales causes de décès, après le cancer et les maladies cardiovasculaires. De plus, les maladies respiratoires représentent la seule cause majeure de décès qui continue d'augmenter $(1,2)$. Des estimations prudentes du fardeau économique des maladies respiratoires l'établissent à 9 milliards de dollars par année, et il risque d'atteindre 15,4 milliards de dollars par année d'ici 2020 (3).

La menace sur la réputation de chef de file mondial

Il est largement entendu que les chercheurs en pneumologie canadiens «jouent dans la cour des grands » sur la scène mondiale. Dans une évaluation sur la productivité en recherche effectuée par Michalopoulos et Falagas (4), les chercheurs canadiens se situaient en quatrième place après l'Europe occidentale, les États-Unis et le Japon, avec un total de 2612 articles entre 1995 et 2003. Ces résultats sont comparables aux 19646 articles publiés par les meilleurs chercheurs en pneumologie d'Europe occidentale. Le Canada bénéficie de la réputation méritée d'être un chef de file mondial en recherche pneumologique, mais on s'inquiète de plus en plus du danger de perdre cette distinction. 
Significant deficiencies in manpower, infrastructure, funding opportunities and training identified by respiratory division directors

Canadian respiratory divisional directors point to significant deficiencies in manpower, infrastructure, funding opportunities and training as major barriers to sustaining or increasing research productivity within their institutions. A recent survey conducted by the CTS, which polled divisional directors across the country $(n=15)$, revealed widespread concern about the future of the clinician/scientist, who many say is in grave danger of extinction! Recurrent themes of this survey included the following:

1. Clinically oriented respiratory research is grossly underfunded given the relatively heavy burden of lung diseases. In support of this contention, current conservative estimates suggest that only approximately $4 \%$ of all federal funding (from the Canadian Institutes of Health Research [CIHR]) is designated for respiratory research. Of this, less than $30 \%$ of the total funding flows to clinical research. Over the past decade, funding agencies have consistently favoured basic over clinical research. The overall success rate for federal (ie, CIHR) funding is approximately $17 \%-$ and even less for clinician researchers. The respiratory panel of the CIHR adjudication committee consists mainly of basic scientists, with minority or 'symbolic' representation of clinician researchers.

2. Few graduates of respirology training programs currently opt for careers in clinical research. Reduced training opportunities and inadequate funding were listed as common obstacles.

3. An overriding concern was the pervasive deficits in funding for health care, a national manpower shortage, and a major institutional focus on clinical and education deliverables at the expense of research promotion.

The issues outlined above constitute significant challenges; however, they are challenges that we are fully determined to address through the following initiatives:

Establishing a new Research Committee, and developing and implementing an action plan: In 2009, a new CTS Research Committee was created under the inspirational leadership of Andrew Halayko. This committee consists of 13 elite respiratory scientists from across the country (more accurately -12 elite scientists and one 'economy class' version - me!) with an expanded mandate to strategically advance the research agenda of the CTS in the coming years. After broad consultation, a research action plan has been finalized and is now in the first phase of implementation. This includes the recruitment of a new expert panel consisting of leading basic and clinician scientists who are charged with the prioritization of research questions using a fair and transparent approach (the Delphi process). Research priorities will be set in asthma, chronic obstructive pulmonary disease, sleep-disordered breathing, infectious diseases and pulmonary arterial hypertension in close collaboration with the respective CTS guidelines committees. Who better to identify the current gaps in scientific knowledge than those who have undertaken a rigorous review of the literature to create best-practice recommendations? This approach will provide the necessary horizontal integration to promote effective new translational research initiatives.
D'importantes carences sur le plan de la main-d'œuvre, des infrastructures, des possibilités de financement et de formation déterminées par les directeurs des unités de pneumologie Les directeurs des unités de pneumologie canadiennes signalent d'importantes carences sur le plan de la main-d'œuvre, des infrastructures, des possibilités de financement et de formation, qui constituent des obstacles marqués au maintien ou à l'accroissement de la productivité en recherche au sein de leur établissement. Un récent sondage mené par la SCT auprès des directeurs d'unités du pays $(\mathrm{n}=15)$, a révélé une inquiétude généralisée quant à l'avenir du clinicien-chercheur qui, selon bon nombre d'entre eux, est en grave danger d'extinction! Les thèmes récurrents de ce sondage s'établissaient comme suit :

1. La recherche clinique en pneumologie est nettement sousfinancée étant donné le fardeau relativement lourd des maladies pulmonaires. En appui avec cette allégation, les estimations prudentes indiquent que seulement $4 \%$ environ de tout le financement fédéral (des Instituts de recherche en santé du Canada [IRSC]) sont affectés à la recherche en pneumologie. De cette proportion, moins de $30 \%$ du financement total sont attribués à la recherche clinique. Depuis dix ans, les organismes subventionnaires ont constamment favorisé la recherche fondamentale aux dépens de la recherche clinique. Le taux de succès global du financement fédéral (c'està-dire les IRSC) est d'environ $17 \%$, et encore moindre à l'égard des cliniciens-chercheurs. Le groupe de pneumologie du comité de sélection des IRSC se compose surtout de chercheurs fondamentaux et d'une représentation minoritaire ou « symbolique » de cliniciens-chercheurs.

2. Peu de diplômés des programmes de formation en pneumologie optent pour une carrière en recherche clinique. Les possibilités de formation réduites et le financement insuffisant sont souvent évoqués comme des obstacles.

3. Les principales craintes étaient les carences profondes du financement des soins de santé, la pénurie nationale de maind'œuvre et l'intérêt primordial des établissements envers les impératifs cliniques et de formation aux dépens de la promotion de la recherche.

Les problèmes précédents posent d'énormes défis, mais nous sommes déterminés à les vaincre grâce aux projets suivants :

La création d'un nouveau comité de recherche et l'élaboration et la mise en ouvre d'un plan d'action : En 2009, un nouveau comité de recherche de la SCT a été formé sous la direction inspirée d'Andrew Halayko. Ce comité se compose de 13 scientifiques de haut niveau des quatre coins du pays (plus précisément, 12 scientifiques de haut niveau et une version « en classe économique ", moi !) dont le mandat élargi consiste à faire progresser le programme de recherche de la SCT de manière stratégique au cours des prochaines années. Après une vaste consultation, un plan d'action de la recherche a été adopté et en est à la première phase de mise en œuvre. Ce processus inclut le recrutement d'un nouveau groupe d'experts composé de cliniciens-chercheurs fondamentaux et cliniques de pointe, responsable d'utiliser une démarche juste et transparente (le processus Delphi) dans l'établissement de priorités de recherche. Ces priorités seront axées sur les domaines de l'asthme, de la maladie pulmonaire obstructive chronique, des troubles respiratoires du sommeil, des maladies infectieuses et de l'hypertension artérielle pulmonaire, en étroite collaboration avec les comités des lignes directrices respectifs de la SCT. Personne n'est mieux placé pour déterminer les lacunes dans les connaissances scientifiques que ceux qui ont entrepris une analyse bibliographique rigoureuse pour créer des recommandations de pratiques exemplaires. Cette démarche assurera 
We are grateful to the Canadian Lung Association (CLA) National Office for its provision of support to this process in the person of Anne Van Dam - an experienced and effective administrator.

Building on our collaboration with the CIHR: The CIHR have recently acknowledged the need to boost clinical/translational research in Canada (5). The CTS supports this proposal and shares the hope that this can be achieved without eroding funding for excellent fundamental research. The CTS Research Committee is in a unique position to inform and contribute to this innovative federal plan - particularly as it pertains to respiratory research. We certainly welcome the opportunity to contribute to any initiative that ultimately benefits Canadians with respiratory diseases.

Capitalizing on our continued collaboration with the CLA: As we move forward in addressing the challenges, we will work closely with our partner - the CLA - with whom we enjoy a harmonious relationship and share the common goal of increasing funding for research. The CLA is committed to improving lung health through research and education and, since its inception, has very successfully taken a leading role in raising public awareness of the common pulmonary conditions. The provincial lung associations have launched many effective programs that have provided structured, patient-centred education on prevention and self-management of lung diseases at a grass-roots level. The CLA has contributed in a major way to the creation of the National Lung Health Framework, and has been relentless in lobbying against tobacco smoking and air pollution.

In 2008, the CLA was ranked sixth among the top 10 national fundraising charities, with annual revenues of more than $\$ 34$ million. Six per cent of the total revenue in that year was spent on research. The CLA provides approximately $\$ 0.5$ million per year for national fellowship and studentship awards. Of the 11 fellowship applications deemed fundable by the adjudication committee in 2009/2010, only two could be awarded. The CTS grant-in-aid competition is not, strictly speaking, national in scope but, rather, is tri-provincial: only Ontario, Alberta and British Columbia currently participate. Annually, they fund more than $\$ 1$ million in grants, with the majority funding basic research. In 2007/2008, \$336,939 supported clinical research, whereas $\$ 840,926$ supported basic research.

The CLA executive and its CEO, along with the leadership of the provincial lung associations, will have a pivotal role to play in the national research agenda. Indeed, the success of this initiative will be substantially bolstered if CLA leaders make a firm commitment to assist in the lobbying of stakeholders to enhance funding. The CTS plans to work very closely with the CLA and encourage it to follow the lead of many of the other major national charities that have explored new, federated research funding models.

Leveraging funding: Finally, after research priorities have been set and partnerships are in place, the next step will be to engage various stakeholders to leverage additional funding. Persuasive business cases will be constructed for each research priority to garner support from various sponsors such as federal and provincial governments, the National Lung Health Framework, the pharmaceutical industry and other funding bodies with an interest in lung health. l'intégration horizontale nécessaire pour promouvoir de nouveaux projets de recherche translationnelle efficaces.

Nous remercions l'Association pulmonaire du Canada (APC) de son soutien pendant ce processus, grâce à madame Anne Van Dam, une administratrice expérimentée et efficace.

Faire fructifier notre collaboration avec les IRSC : Les IRSC ont récemment convenu de la nécessité d'accroître la recherche clinique et translationnelle au Canada (5). La SCT appuie cette proposition et partage l'espoir d'y parvenir sans éroder le financement pour l'excellente recherche fondamentale. Le comité de recherche de la SCT est dans une position idéale pour inspirer ce plan fédéral novateur et y contribuer, notamment en matière de recherche respiratoire. En tout cas, nous accueillons cette occasion de contribuer à tous les projets qui finiront par profiter aux Canadiens atteints d'une maladie respiratoire.

Tirer profit de notre collaboration continue avec l'APC : Tandis que nous tenterons de régler les problèmes, nous travaillerons en étroite collaboration avec notre partenaire, l'APC, avec qui nous entretenons une relation harmonieuse et nous partageons l'objectif commun d'accroître le financement de la recherche. L'APC est engagée à améliorer la santé pulmonaire par la recherche et l'éducation et, depuis sa création, a pris les devants avec grand succès pour sensibiliser le public aux maladies pulmonaires courantes. Les associations pulmonaires provinciales ont lancé de nombreux programmes efficaces qui ont fourni une éducation structurée et axée sur le patient en prévention et en prise en charge autonome des maladies pulmonaires auprès du public. L'APC a joué un rôle prépondérant dans la création du Cadre de travail national sur la santé pulmonaire et exerce inlassablement des pressions contre le tabagisme et la pollution de l'air.

En 2008, l'APC est arrivée en sixième place des dix principaux organismes de bienfaisance nationaux faisant de la collecte de fonds, avec des revenus annuels de plus de 34 millions de dollars. Six pour cent des revenus totaux ont alors été affectés à la recherche. L'APC distribue environ 0,5 million de dollars par année en subventions nationales à des étudiants en médecine ou au doctorat. Des 11 demandes de bourse au postdoctorat jugées subventionnables par le comité de sélection en 2009-2010, seulement deux ont pu être accordées. Le concours de bourse en aide à la recherche de la SCT n'est pas d'envergure nationale à proprement parler, mais triprovincial. En effet, seules l'Ontario, l'Alberta et la Colombie-Britannique y participent actuellement. Tous les ans, l'APC octroie plus d'un million de dollars en subventions, la plupart axées sur la recherche fondamentale. En 2007-2008, 336939 \$ ont été attribués à la recherche clinique, et 840926 \$à la recherche fondamentale.

Le comité directeur et la directrice générale de l'APC, de même que la direction des associations pulmonaires provinciales, auront un rôle essentiel à jouer dans le programme de recherche national. En effet, la réussite de ce projet serait grandement favorisée si la direction de l'APC s'engageait fermement à participer au lobbying auprès des intervenants afin d'accroître le financement. La SCT prévoit travailler de très près avec l'APC et l'encourager à suivre la voie tracée par de nombreux autres organismes de bienfaisance nationaux qui ont exploré de nouveaux modèles fédérés de financement de la recherche.

Obtenir du financement : Enfin, après avoir mis en place des priorités et des partenariats de recherche, la prochaine étape consistera à inciter divers intervenants à collaborer avec nous dans la quête de financement supplémentaire. Des dossiers d'analyse persuasifs seront préparés pour chaque priorité de recherche afin d'obtenir le soutien de différents commanditaires, comme les gouvernements fédéral et provinciaux, le Cadre de travail, l'industrie 
Many other initiatives are in the works. There is a renewed emphasis on training of young researchers and a plan to increase funding for fellowships and studentships in the immediate future. The Research Committee is also charting the topography of respiratory research across the nation. In addition, it is creating a website to enhance communication between researchers and to facilitate the creation of future research networks. We are also working on integrating more research content into the successful annual Canadian Respiratory Conference and improving communication (social and scientific) among young investigators. Likewise, the American Thoracic Society has agreed to provide a new Canadian forum (a poster session) for the exclusive purpose of highlighting Canadian research at the 2011 American Thoracic Society meeting in Denver, Colorado (USA).

Clearly, the CTS Research Committee has developed a very ambitious plan to tackle these considerable challenges; however, it will not succeed in isolation. The support of our key partners, including the CLA and CIHR, will be vital. Efforts are also underway to engage academic leaders (divisional and program directors) from across the nation. Obviously, unified support from this key group is a prerequisite for our success.

Support of the broader respiratory community, including you, is also something we count on in this most vital initiative - to establish a strong respiratory research agenda that leads to improvements in the respiratory health of all Canadians, now and for the years to come.

\section{I look forward to your support!}

\author{
Respectfully submitted, \\ Denis E O'Donnell MD FRCPI FRCPC \\ President, Canadian Thoracic Society
}

\section{REFERENCES}

1. Public Health Agency of Canada. Leading causes of death and hospitalization in Canada, 2004. <http:/www.phac-aspc.gc.ca/ publicat/lcd-pcd97/index-eng.php $>$ (Accessed on May 31, 2010).

2. Estimated DALY for Canada 2002. (WHO Global Burden of Disease Project) <http://www.who.int/topics/global_burden_of_ disease/en/> (Accessed on May 31, 2010).

3. National Health Expenditure Trends, 1975-2009. Canadian Institute for Health Information, 2009. < http://secure.cihi.ca/cihiweb/dispPage. jsp?cw_page=AR_31_E $>$ (Accessed on May 31, 2010).

4. A Michalopoulos, ME Falagas. A bibliometric analysis of global research production in respiratory medicine. Chest 2005;128;3993-8.

5. Strategy for Patient-Oriented Research. <www.cihr-irsc.gc.ca> (Accessed on May 31, 2010). pharmaceutique et d'autres organismes subventionnaires intéressés par la santé pulmonaire.

De nombreux autres projets sont en préparation. On recommence à mettre en valeur la formation des jeunes chercheurs et on élabore un plan d'accroissement du financement des subventions à la recherche et des bourses d'études. Le comité de recherche est à cartographier la topographie de la recherche respiratoire au pays. De plus, il crée un site Web pour améliorer les communications entre chercheurs et faciliter la formation de futurs réseaux de recherche. Nous travaillons également à intégrer un contenu de recherche plus abondant au Congrès canadien sur la santé respiratoire et à améliorer les communications (sociales et scientifiques) entre jeunes chercheurs. De même, l'American Thoracic Society a accepté de fournir une nouvelle tribune canadienne (une séance d'affiches) dans le but exclusif de faire ressortir la recherche canadienne à son congrès qui aura lieu à Denver, au Colorado (ÉtatsUnis) en 2011.

De toute évidence, le comité de recherche de la SCT a préparé un plan très ambitieux pour affronter ces défis considérables. Cependant, il ne réussira pas tout seul. L'appui de ses partenaires clés, y compris l'APC et les IRSC, sera essentiel. Des efforts sont également consentis pour faire participer les chefs universitaires (directeurs d'unités et de programmes) du pays. Bien sûr, l'appui unifié de ce groupe clé est nécessaire à notre réussite.

Nous comptons également sur l'appui de l'ensemble de la communauté de la pneumologie pour ce projet vital, y compris sur le vôtre, afin de mettre sur pied un programme de recherche en pneumologie qui entraînera des améliorations à la santé respiratoire de tous les Canadiens, maintenant et pour les années à venir.

J'espère compter sur votre appui !

Amicalement, Denis E O'Donnell MD FRCPI FRCPC Président, Société canadienne de thoracologie

\section{RÉFÉRENCES}

1. Agence de la santé publique du Canada. Principales causes de décès et d'hospitalisation au Canada, $2004<$ www.phac-aspc.gc.ca/ publicat/lcd-pcd97/index-fra.php > (consulté le 31 mai 2010).

2. Estimated DALY for Canada 2002 (Charge mondiale de morbidité de l'OMS) <www.who.int/topics/global_burden_of_disease/fr/index. html> (consulté le 31 mai 2010).

3. Tendances des dépenses nationales de santé, 1975-2009. Institut canadien d'information sur la santé, $2009<$ http://secure.cihi.ca/ cihiweb/dispPage.jsp?cw_page=AR_31_F> (consulté le 31 mai 2010).

4. A Michalopoulos, ME Falagas. A bibliometric analysis of global research production in respiratory medicine. Chest 2005;128;3993-8.

5. Stratégie de recherche axée sur le patient. <www.cihr-irsc.gc.ca> (consulté le 31 mai 2010). 


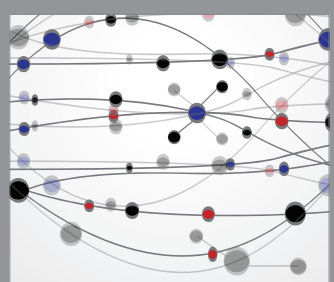

The Scientific World Journal
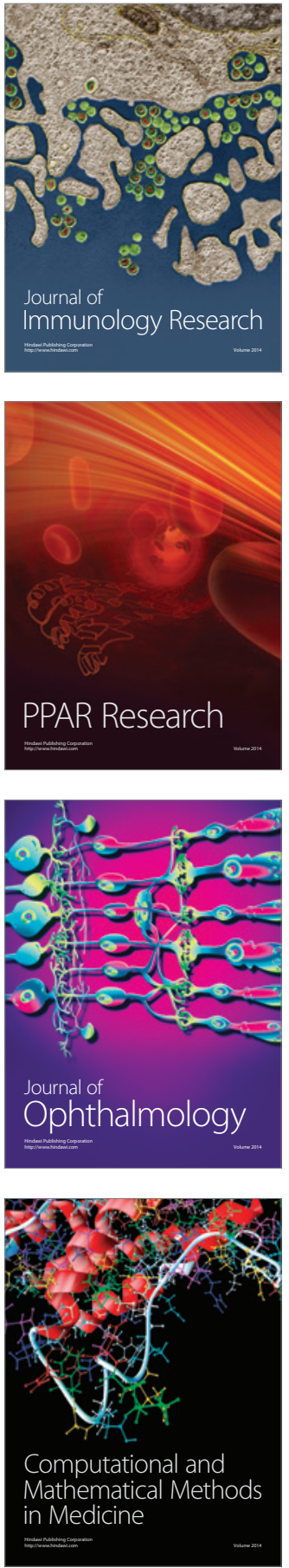

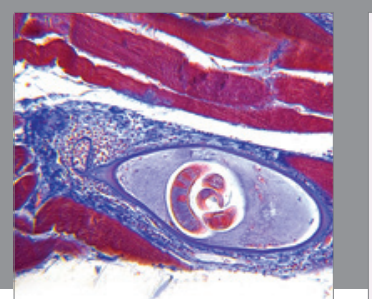

Gastroenterology Research and Practice

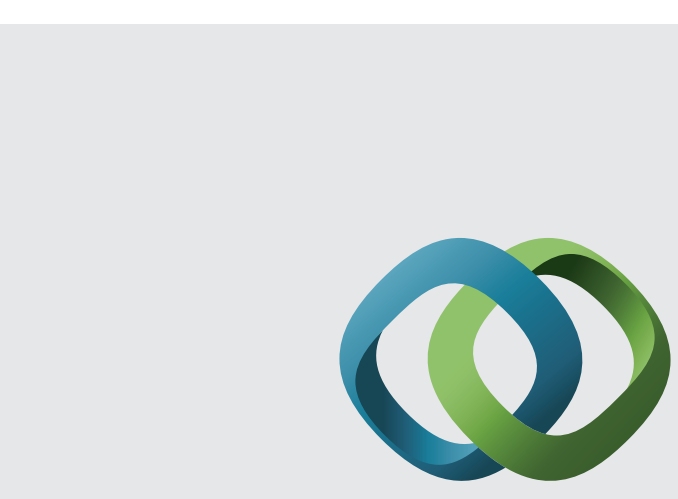

\section{Hindawi}

Submit your manuscripts at

http://www.hindawi.com
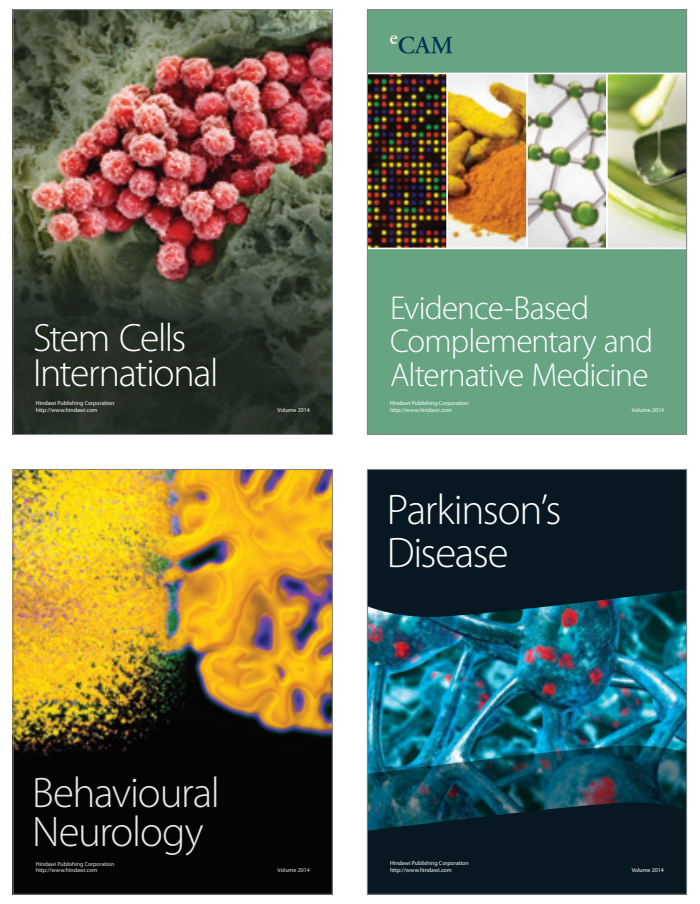
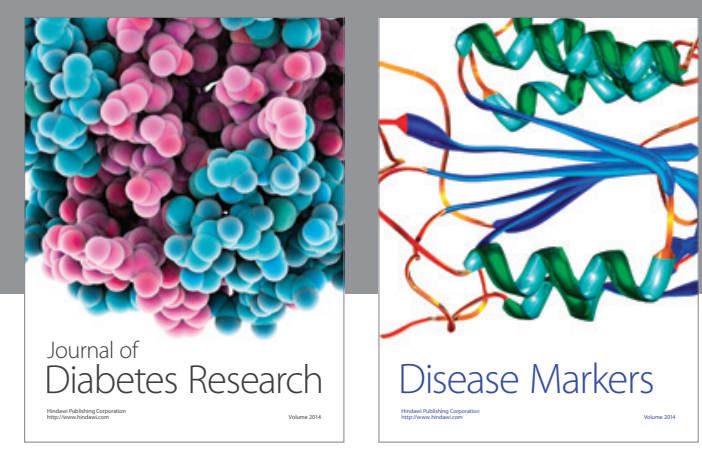

Disease Markers
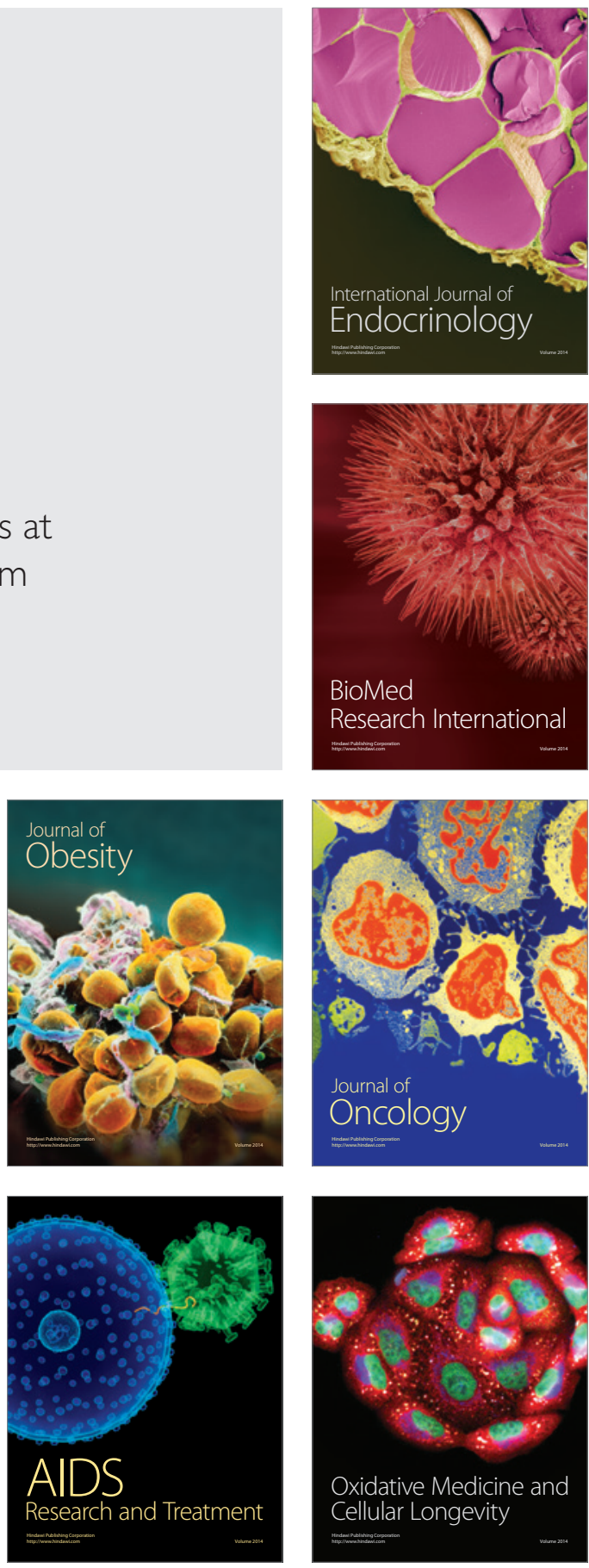